\title{
THE DETERMINATION OF POTASSIUM IN CARDIAC MUSCLE AND THE PRESUMABLE INFLUENCE OF THE BETA RADIATIONS ON THE RHYTHM
}

\author{
By L. C. SCOTT \\ (From the Department of Tropical Medicine, Tulane University, New Orleans)
}

(Receved for publication May 18, 1931)

A summary of a fairly large series of analyses on cardiac muscle for the principal inorganic constituents was published some time ago (Scott (1)). These determinations included both potassium and sodium and the method seemed sufficiently convenient and accurate at the time. However, it occurred to the author that at least for potassium, the function of which appears to be both complex and important, the procedure might be simplified somewhat, thus enabling one to obtain even more reliable data, and finally to apply the results so obtained to the calculation of the kinetic energy developed by the emanation of the active Beta particles.

For this reason a second series of determinations of potassium on thirty hearts was carried out, and the work was simplified by the omission of steps unavoidable in the first. This was conducive to greater accuracy and it is believed that the results are as close an approximation to the true potassium content as it is now possible to obtain.

A certain amount of controversy has arisen over the advisability of dry ashing organic material containing alkali salts. However, Raab (2) used dry ashing and Egg and Klinke (3) employed Stolte's method with good results. Constantino (5) used a modification of the dry incineration method which in the end involved heating to drive off sulphuric acid. Ernst and Scheffer (6) showed conclusively not only by incineration of dried muscle but also by exposure of potassium salts alone to long periods of heating that the objections of other observers are not tenable, and their tables indicate that no appreciable losses occur even after six days in an electric furnace. 
This is in a measure confirmed by the findings with 6.1621 grams $\mathrm{KCl}$. The salt which had been dried was heated in a palaurium dish for three and one half hours to a faint red heat insufficient to melt it completely, weighings being made at intervals of 1 hour, 20 minutes, 1 hour, and 1 hour and 10 minutes. The losses which may be attributed to water held tenaciously by the crystalline salt were respectively $0.0023,0.0028$, and 0.0062 grams. This was followed by a period of heating for six hours with three weighings at 1 hour and 10 minute intervals and two more at 1 hour and 15 minute intervals. The results were, in order of the weighings, $-0.0002,+0.0004,-0.0002,+0.0001$ and +0.0001 gram, that is, there was virtually no loss whatever. The increases in weight may have been due to moisture absorption while weighing. When, however, the heat was increased and the salt kept in a fluid condition for 1 hour and 5 minutes the loss was 0.1693 gram and white fumes were given off. This degree of heat was never applied to the incineration of the tissue, and is moreover not necessary. The latter process required as a rule two and one half to three hours and the silica dish in which it was carried out never showed more than a faint red, nor was the ash ever allowed to melt.

Duplicates made by myself on cardiac tissue heated three to four hours agree extremely well in the ash content. Obviously there is small chance of error from this source.

\section{METHOD}

The choice of the method for estimating the potassium was decided upon after careful review of the literature and insofar as accuracy is concerned the old chloroplatinate precipitation method does not appear to have been surpassed.

No moisture determinations were made. Sixty grams of fresh ground heart muscle were dried thoroughly in a silica dish and the contents ashed at a very faint red heat. The temperature was kept low in order to avoid melting the ash in which case it is sometimes impossible to get rid of all the carbon and the ash is not always white. Some ashes resist heating for periods longer than it is desirable to keep the dish over the flame. For this reason the ash percentages are only approximately correct in the second and third decimal places.

When incineration was complete and after weighing, the ash was 
treated with strong $\mathrm{HCl}$ and evaporated to dryness, it was again heated to dehydrate silicic acid, redissolved with a few drops of $\mathrm{HCl}$ and carefully transferred to a $150 \mathrm{cc}$. beaker. Strong ammonia was added and the solution stirred thoroughly, scraping the sides of the beaker with the rod. This precaution facilitates the separation of the magnesium. Clear lime water from C.P. $\mathrm{CaO}$ was added to get rid of most of the phosphates and finally slight excess of saturated ammonium oxalate solution to precipitate the lime. No attempt was made to free the solution completely of phosphates, nor is it necessary. Ferric phosphate, however, is troublesome and it passes the filter in small amounts despite the use of wash water containing ammonium hydroxide and ammonium acetate. As will be observed, this possible chance for error is taken care of later.

After standing over night the precipitate is compact and may be readily removed by filtration. The filtrate was diluted to $500 \mathrm{cc}$. in a calibrated measuring flask to which a two drop $50 \mathrm{cc}$. pipette had been adapted.

For each determination $50 \mathrm{cc}$. equivalent to 6 grams of heart muscle were measured into a beaker and evaporated carefully to dryness on a hot plate. It is advisable to acidify with $\mathrm{HCl}$ after the free ammonia has been driven off to minimize the danger of spattering. The ammonia salts were then expelled, the residue taken up with 2 drops of concentrated $\mathrm{HCl}$ and $5 \mathrm{cc}$. of water. Platinum chloride (approximately 10 per cent) in excess was added, and the contents evaporated slowly on a water bath, care being taken not to place the beakers in contact with the steam. Complete dryness was however avoided. In the latter event, one or two drops of $\mathrm{HCl}$ and a few cubic centimeters of water were added, and the evaporation repeated.

When the proper condition had been attained, that is with the residue still moist, the beaker was removed, cooled and diluted with 1-2 cc. of water and 95 per cent alcohol added in small quantities. The first addition should be about 5-10 cc. in which the crystals of chloroplatinate are broken and ground up with a stirring rod provided with a flattened end. Afterward the remainder of the alcohol up to $50 \mathrm{cc}$. may be added, the whole stirred thoroughly and allowed to stand 3-4 hours or preferably over night.

The potassium chloroplatinate was filtered off in Gooch crucibles 
having mats made from asbestos that had been thoroughly digested with strong $\mathrm{HCl}$ and washed. The reduction and subsequent manipulations are otherwise the usual ones given for this method. The weight of reduced $\mathrm{Pt} \times 0.3993=\mathrm{K}$ in grams.

One point, however, deviates somewhat from the routine. This consists in moistening the reduced platinum with a few drops of strong $\mathrm{HCl}$ after removing the soluble salts with hot water and again washing with hot water. By this precaution and by dissolving the alkali residue in the beaker with $\mathrm{HCl}$ before precipitation with platinic chloride solution and furthermore by keeping the chloroplatinate precipitate faintly acid the error due to ferric phosphate may be avoided. Sodium phosphate does not influence the precipitation of potassium, and lime and magnesium are eliminated, so that the only sources of error aside from those defects inherent in the method itself appear to be taken care of fairly well. The faint excess of $\mathrm{HCl}$ does not seem to increase the solubility of potassium chloroplatinate in the alcohol. Neubauer (7) showed that quite appreciable quantities of sulphuric acid did not vitiate the end results.

\section{Checks}

A number of the hearts were assayed in duplicate. That is, two 60 gram portions were taken. Usually but not always these checked very closely with one another. As a rule, however, three to six $50 \mathrm{cc}$. portions of the diluted ash solution each representing 6 grams of the original heart were used, and there is no reason to think that duplicates were necessary.

These determinations always agreed to the second place and no series is included that did not check in at least three and ordinarily five determinations within the third decimal place. When three very close checks were obtained no further determination was made. As examples, the following may be cited. Heart number 128 showed $0.178,0.182,0.178,0.173$ per cent $\mathrm{K}$ while heart number 140 which is not so close gave the following figures: $0.319,0.317,0.329,0.324,0.320$ per cent $\mathrm{K}$.

Altogether 120 determinations of $\mathrm{K}$ were made on thirty hearts and of these, eight have five checks which were used in estimating the probable error of the individual determination. This was obtained by using the formula $\pm 0.6745 \mathrm{~S}$ where $\mathrm{S}$ is the standard deviation for a 
series of checks. The probable errors were respectively \pm 0.0018 , $\pm 0.0014, \pm 0.0025, \pm 0.0012, \pm 0.0027, \pm 0.0027, \pm 0.0027, \pm 0.0021$ yielding a mean P.E. for individual determinations of \pm 0.0021 gram K per 100 grams.

An additional check on the method consisted in determining the $\mathrm{K}$ in a mixture of disodium phosphate and potassium chloride approximating conditions in the heart sample. The results are expressed in Table 1. They furnish, I think, a fair demonstration that phosphates do not influence the accurate determination of $\mathrm{K}$ in mixtures.

TABLE 1

Determination of potassium in the presence of phosphates

$0.2500 \mathrm{KCl}$ and 0.5000 gram $\mathrm{Na}_{2} \mathrm{HPO}_{4} \cdot 12 \mathrm{H}_{2} \mathrm{O}$ to $500 \mathrm{cc}$.

50 cc. equivalent to $0.0250 \mathrm{KCl}$ and $0.0500 \mathrm{Na}_{2} \mathrm{HPO}_{4} \cdot 12 \mathrm{H}_{2} \mathrm{O}$ per determination.

\begin{tabular}{|c|c|c|}
\hline $1 \ldots \ldots \ldots \ldots \ldots$ & $\begin{array}{c}\text { Pt found, } \\
\text { grams } \\
0.0338\end{array}$ & $\begin{array}{c}\mathrm{KCl} \\
\text { grams } \\
\mathbf{0 . 0 2 5 7}\end{array}$ \\
\hline $2 \ldots \ldots \ldots \ldots \ldots$ & 0.0336 & 0.0256 \\
\hline $3 \ldots \ldots \ldots \ldots \ldots$ & 0.0334 & 0.0254 \\
\hline $4 \ldots \ldots \ldots \ldots \ldots$ & 0.0334 & 0.0254 \\
\hline $5 \ldots \ldots \ldots \ldots \ldots$ & 0.0330 & 0.0250 \\
\hline $6 \ldots \ldots \ldots \ldots, \ldots$ & 0.0330 & 0.0250 \\
\hline $7 \ldots \ldots \ldots$ & 0.0334 & 0.0254 \\
\hline
\end{tabular}

(The $\mathrm{KCl}$ used was B. and A.C.P. salt. The $\mathrm{Na}_{2} \mathrm{HPO}_{4}$ was marked C.P. but the origin is unknown. One gram yielded 0.0074 gram $\mathrm{Pt}=0.00028$ gram $\mathrm{KCl}$ for 0.0500 gram $\mathrm{Na}_{2} \mathrm{HPO}_{4} \cdot 12 \mathrm{H}_{2} \mathrm{O}$.)

A summary of the data derived from the analyses including the probable error and standard deviation is shown in Table 2. The probable error of the mean is determined from the formula $\pm \frac{0.6745 \mathrm{~S}}{\sqrt{\mathrm{N}}}$ in which $\mathrm{S}$ is the standard deviation and $\mathrm{N}$ the number of observations. There is considerable variation in the means of the individual deter-

TABLE 2

Summary of analyses on moist tissue of 30 hearts

\begin{tabular}{|c|c|}
\hline Ash & Potassium \\
\hline $\begin{array}{l}\text { grams per } 100 \text { grams moist } \\
\ldots \ldots \ldots \ldots . \quad 0.976\end{array}$ & $\begin{array}{c}\text { grams per } 100 \text { grams moist } \\
0.231\end{array}$ \\
\hline Probable error of mean... \pm 0.0157 & \pm 0.0066 \\
\hline tandard deviation. . . . . . & 0.0538 \\
\hline
\end{tabular}


minations. For example the ash varied from a minimum of 0.691 per cent to a maximum of 1.290 per cent, the potassium from a minimum of 0.129 per cent to a maximum of 0.316 per cent. The lower figures for ash and $\mathrm{K}$ were obtained on a small, soft, flabby, thin walled and obviously much degenerated heart from a man 69 years old, while the highest were also from a relatively small but thick walled male heart.

In general it cannot be said that either pathological changes, age of patient, illness that was responsible for death or any other factor is in any way correlated with the potassium content. This observation with reference to other inorganic constituents has already been noted (Scott (1)).

\section{Edema and potassium content of heart muscle}

Among the hearts in this series there were seven from patients showing unmistakable signs of cardiac failure with edema. There were probably more but nothing definite can be obtained from the records. The potassium content of these hearts is compared with that of an equal number from patients dying of diseases in which edema did not occur. The latter comprised three from tuberculous patients and one each from victims of bronchopneumonia, epithelioma, duodenal ulcer, and lues with resultant complications.

The mean of the potassium in hearts from the seven patients with edema was 0.220 per cent, and from the seven non-edematous cases 0.218 per cent. This agrees approximately with a series of determinations of potassium and sodium on fifteen hearts from edematous patients and a like number from non-edematous cases previously reported by Scott (8). The present analyses are believed to be more accurate but are merely confirmatory. In neither series is there evidence that the myocardium contains more or less potassium when the individual dies of cardiorenal failure with edema than when he succumbs to another disease not productive of edema. This is not in agreement with the observation of Harrison, Pilcher, and Ewing (9), who concluded that with chronic congestive heart failure the cardiac muscle contained less potassium than in other diseases producing death.

Possible effects of $\beta$-radiations of potassium on the heart muscle

In 1908 Campbell and Wood (10), Campbell $(11,12)$ alone and McLennan and Kennedy (13) demonstrated beyond a doubt that the 
potassium atom is continuously disintegrating with the emanation of Beta particles and the concensus of opinion seems to be that with the exception of very minute quantities of radium it is the only radioactive element in the human body.

On the basis of these and other observations and by comparing the activity of potassium with that of uranium, rubidium and radium, Zwaardemaker (14-15) estimated the kinetic energy produced by the Beta particles of $\mathrm{K}$ in the human heart weighing 300 grams as 4.1 $\times 10^{-4}$ ergs per second.

That this estimate is far too high can readily be shown when we consider the recent investigations of Mühlhoff (16), who also exhaustively cites prior contributions on the subject. Furthermore, Zwaardemaker assumed that the Beta particles of potassium have an average velocity approximating 66 per cent that of light, whereas Kovarik (17) states that absorption coefficients indicate the velocity to be between 82 and 83 per cent.

Besides Beta particles the potassium atom also produces Gamma radiations. These have been definitely established by Mühlhoff (16), Kohlhorster (18) and Behounek (19). Unfortunately the evaluation of Gamma rays in terms of kinetic energy is not feasible and at present only the estimation of the kinetic energy developed by the Beta particles is possible.

By employing the absolute number of 23 Beta emanations per second per gram of the element potassium as given by Mühlhoff, and taking the average velocity to be 82 per cent that of light, one can readily calculate the kinetic energy developed by one milligram of $K$.

The energy of a Beta particle with a velocity of $v=\beta c$ is

$$
E=m_{0} c^{2}\left[\left(1-\beta^{2}\right)^{-1 / 2}-1\right] \quad \text { (Kovarik and McKeehan (20)), }
$$

in which $m_{0}$, the mass of a slowly moving electron, is $9 \times 10^{-28}$ grams, $c$ the velocity of light, $2.9986 \times 10^{+10} \mathrm{~cm}$. per second, and $\beta$ the ratio of the velocity of the Beta particle to the velocity of light, in this instance 0.82 . The kinetic energy developed by 0.001 gram $K$ is thus shown to be $1.392 \times 10^{-8}$ ergs per second.

Now assuming that the mean percentage of potassium in the heart muscle is approximately 0.231 per cent, then the disintegration of the atoms of this element will develop $9.64 \times 10^{-6}$ ergs per second in a heart containing 300 grams of muscular fibers. 
This amount of energy may appear to be extremely minute but it is hundreds times greater than the minimum necessary to stimulate either the optic or the auditory nerve endings and moreover it is continuous from birth to death, varying only in degree.

The experimental work of $Z$ waardemaker has shown that other radioactive and, insofar as tissue is concerned, chemically inert substances are interchangeable with potassium, which makes it evident that the radioactive character of potassium exerts a tremendously important influence on rhythmicity. One may readily conceive that the free energy 0 ? the Beta particles can be cumulative and reaching a maximum transform the potential energy of the heart muscle in response to node and bundle impulses into the enormously greater manifestation of kinetic energy, the systolic contraction. This would constitute the function of potassium in the heart muscle in some respects analogous to that of the cap on a high explosive charge, either directly or indirectly as a detonator.

Such a conception of the rôle of potassium taken in conjunction with Howell and Duke's (21) observations that vagus irritation increases potassium elimination might afford a rational picture of the phenomenon of ectopic beats as well as of other disturbances of cardiac rhythm.

\section{SUMMARY AND CONCLUSIONS}

1. It is believed that the method employed for the determination of potassium in the human heart muscle yields quite accurate results.

2. The mean percentage of potassium expressed as the element $K$ was found to be 0.231 per cent.

3. There is no material difference between the content of potassium in hearts from edematous and non-edematous cases.

Acknowledgment is herewith gratefully accorded Prof. D. S. Elliot of Tulane and Prof. A. F. Kovarik of Yale University for their kindly suggestions.

\section{BIBLIOGRAPHY}

1. Scott, L. C., J. Clin. Invest., 1930, ix, 463. The Proportion of Certain Important Inorganic Constituents in the Dying Heart Muscle.

2. Raab, E., Arch. f. d. ges. Physiol., 1927, ccxvi, 540. Über die Bindung des Kaliums im Muskel.

3. Egg, C., and Klinke, K., Biochem. Ztschr., 1927, cxci, 439. Über die 
Anwendung der Stolteschen Veraschungsmethode in der Mikroanalyse.

4. Stolte, K., Biochem. Ztschr., 1911, xxxv, 104. Eine einfache und zuverlässige Methodik der Aschenanalyse.

5. Constantino, A., Biochem. Ztschr., 1911. xxxvii, 52. Über den Gehalt der (weissen und roten) quergestreiften und glatten Muskeln verschiedener Tiere an Kalium, Natrium und Chlor.

6. Ernst, E., and Scheffer, L., Arch. f. d. ges. Physiol., 1928, ccxx, 655. Untersuchung über Muskelkontraktion. VII. Die Rolle des Kaliums in der Kontraktion.

7. Neubauer, H., Ztschr. f. Analyt. Chem., 1900, xxxix, 481. Eine abgekürzte Methode der Kalibestimmung in den Kalisalzen.

8. Scott, L. C., Arch. Int. Med., 1931, xlvii, 116. The Potassium Content of the Hearts of Persons Dying from Edematous and Nonedematous Conditions.

9. Harrison, T. R., Pilcher, C., and Ewing, G., J. Clin. Invest., 1930, viii, 325. Studies in Congestive Heart Failure. IV. The Potassium Content of Skeletal and Cardiac Muscle.

10. Campbell, N., and Wood, A., Proc. Camb. Phil. Soc., 1908, xiv, 15. The Radioactivity of the Alkali Metals.

11. Campbell, N., Proc. Camb. Phil. Soc., 1908, xiv, 211. The $\beta$-Rays from Potassium.

12. Campbell, N., Proc. Camb. Phil. Soc., 1909, xv, 11. The Radioactivity of Rubidium.

13. McLennan, J. C., and Kennedy, W. T., Phil. Mag. (London, Edinburgh and Dublin), 1908, xvi, 377. On the Radioactivity of Potassium and Other Alkali Metals.

14. Zwaardemaker, H., Ergebn. d. Physiol., 1921, xix, 337. Über die Bedeutung der Radioaktivität für das tierische Leben.

15. Zwaardemaker, H., Arch. f. d. ges. Physiol., 1926-27, ccxv, 460. Über das Erwachen des durch Kaliumentziehung zur Ruhe gekommenen Herzens durch die Bestrahlung des Radiums.

16. Mühlhoff, W., Annal. d. Physik., 1930, vii, 205. Aktivität von Kalium und Rubidium gemessen mit dem Elektronenzählrohr.

17. Personal communication from Prof. Kovarik.

18. Kohlhorster, W., Naturwissenschaften, 1928, xvi, 28. Gammastrahlen an Kaliumsalzen.

19. Behounek, F., Nature, 1930, cxxvi, 243. The Gamma Rays of Potassium.

20. Kovarik, A. F., and McKeehan, L. W., Bull. Natl. Research Council, 1929, No. 51, 84. Radioactivity. Report of Committee on X-Rays and Radioactivity, National Research Council.

21. Howell, W. H., and Duke, W. W., Am. J. Physiol., 1908, xxi, 51. The Effect of Vagus Inhibition on the Output of Potassium from the Heart. 